УДК 882

КОЛОНИАЛЬНАЯ И ПОСТКОЛОНИАЛЬНАЯ ЛИТЕРАТУРА:
ТЕРМИНОЛОГИЯ И СОДЕРЖАНИЕ

(C) Элеонора Шафранская

\title{
COLONIAL AND POST COLONIAL LITERATURE: TERMINOLOGY AND CONTENT
}

\begin{abstract}
Eleonora Shafranskaya
In some academic communities, the terms "colonial" and "postcolonial" cause rejection being perceived as anti-Russian marks when used in relation to Russian literature. The article aims, if not to soften this perception, then to methodically introduce these terms into a literary discussion. The previous article, "Phases of Colonial Discourse in Russian Prose about Turkestan", published in the second issue of the journal "Filologiia i kultura. Philology and Culture" in 2017, made the emphasis on "time phases" both in history and literature on Central Asia. This one will focus on enriching the terms colonial and postcolonial with the material from Russian literature of the $20^{\text {th }}$ and $21^{\text {st }}$ centuries. The article highlights post-colonial issues in Juri Karabchievsky's travelogue "Longing for Armenia", written long before the collapse of the empire, and in post-empire works by Suhbat Aflatuni. We consider the specifics of postcolonial literary methods, and, in particular, the metaphor "stagnation - lethargarium", and outline the portrait of the lyrical hero in Sanjar Yanyshev's poetic prose, which is a palimpsest of the colonial and post-colonial periods of Soviet history and modernity. Yanyshev's lyrical hero is phenomenal as a focal point of today that echoes all traumatic and semi-conscious twists and turns of the twentieth century.
\end{abstract}

Keywords: colonial literature, Turkestan studies, Nikolay Karazin, postcolonial literature, modern Russian prose, Yuri Karabchievsky, Sukhbat Aflatuni.

Термины ко л о н и альн ны й и п о с т к о ло н и а ль н ы й применительно к русской литературе в ряде академических сообществ вызывают отторжение, воспринимаются как антирусские метки. Статья направлена если не на смягчение подобного восприятия указанных терминов, то в какой-то мере на методичное их внедрение в научный дискурс о русской литературе. Если в предыдущей нашей статье «Фазы колониального дискурса в русской литературе о Туркестане», опубликованной в 2017 году во втором номере журнала «Филология и культура. Philology and Culture», основной акцент был сделан на временные фазы как в истории, так и в литературе, посвященной Средней Азии, то в данной статье речь пойдет о наполнении терминов к о л о н и а л ь н ы й и п о с т к о л о н и а ль н ы й материалом из русской литературы XX и XXI веков. Основное внимание уделено постколониальным вопросам в травелоге Юрия Карабчиевского «Тоска по Армении», написанном задолго до развала империи, осмыслению постсоветских и постимперских проблем в прозе Сухбата Афлатуни. Сделан акцент на специфике приемов постколониальной литературы: в частности, рассмотрена метафора стагнации - летаргарий. Эскизом дан портрет лирического субъекта стихотворной прозы Санджара Янышева, в которой прочитывается палимпсест колониального и постколониального периодов советской истории и современности. Лирический герой Янышева феноменален как средоточие всех травматических, полуосознанных перипетий двадцатого столетия, отзывающихся в дне сегодняшнем.

Ключевые слова: колониальная литература, туркестановедение, Николай Каразин, постколониальная литература, современная русская проза, Юрий Карабчиевский, Сухбат Афлатуни.

Программа конференции «Нации и этничность в гуманитарных науках. Колониализм и неоколониализм: дискурсы и практики», прошедшей в Санкт-Петербургском государственном университете в феврале 2018 года, выглядит как некий срез материала, на котором исследуется проблема колониальности и постколониально- сти в литературе: в подавляющем большинстве это англоязычная литература (американская, британская, индийская), а также французская, польская, болгарская, сербская и др. Русская литература не часто выступает объектом колониального и постколониального дискурса. Сказывается советская инерция, выраженная в том, что 
и дореволюционная Россия, и Советский Союз не колониальные державы. Хотя это не так, и уже давно веско и аргументированно доказано обратное. По словам Ольги Брейнингер, «постколониализм, столь популярный на Западе, на литературной карте России продолжает оставаться белым пятном. Сам термин иной раз встречается в критике, но так редко, что нельзя не согласиться с В. Чернецким в том, что он продолжает оставаться ,единственным из больших современных теоретических дискурсов, который гордо и последовательно отвергается в современной России“ <..> Корпус работ, серьезно разрабатывающих постколониальный дискурс применительно к русской литературе, невелик, и показательно, что большинство из них написано или западными учеными, или российскими литературоведами, связанными с западной академией, такими как А. Эткинд или Г. Гусейнов [Брейнингер, с. 166]. По наблюдениям современных исследователей, «еще в 1830-е годы русская проза второго ряда <..> была богата ориенталистско-колониальными сюжетами — „кавказскими“, „калмыцкими“ и т. д. <..> Показательно, однако, что значительная часть ориенталистики была „вытеснена“ из русской литературы в процессе формирования литературного канона - или не была опознана в качестве ориенталистской литературы; так случилось с „Героем нашего времени“» [Эткинд, Уффельман, Кукулин, с. 16] - и не только; говоря о колониально-ориенталистских сюжетах непременно надо обращаться и к «Господам ташкентцам» Михаила СалтыковаЩедрина, ряду произведений Николая Лескова, Льва Толстого и др. писателей XIX в.

В статье речь пойдет о наполнении заявленных терминов содержанием постколониального научного дискурса, а также материалом русской литературы XIX-XXI вв.

Под колониальной литературой мы понимаем ту, где повествуется о событиях, связанных с процессом колонизации, не без антиколониальных обертонов.

Под постколониальной литературой - ту, в которой осмысляется эпоха колонизации, и не только после распада советской империи, много раньше.

В некоторых академических сообществах термины колониальная и постколони альная литература вызывают отторжение, точнее непонимание, воспринимаются как антирусский дискурс. Мне пришлось с этим столкнуться напрямую. Когда я выступила инициатором и организатором конференции по колониальной и постколониальной литературе, получила от руководства отповедь и запрет на проведе- ние конференции, в тексте содержались такие слова: «Мы сошлись во мнении, что эта терминология некорректна ни с точки зрения исторической науки, ни с точки зрения истории литературы, крайне тенденциозна, политизирована... более того, оскорбительна как для русского народа, так и для любого народа СССР или России. $<\ldots>$ Если в отдельных странах СНГ эти термины (фигурально, в кавычках) и употребляются, то нам, и по отношению к русской литературе, использовать их по меньшей мене странно». А рецензент магистерской работы о русской колониальной литературе написал, что подобная терминология несет «ненависть к России как к историческому, культурному, религиозному и т. д. уникуму».

С одной стороны, приведенные примеры иллюстрируют инерцию сервильного сознания, находящегося в тисках исторической травмы, с другой, очевидной, - мракобесие.

Расстрелянный в 1938 г. и ныне забытый русский писатель Борис Чепрунов запечатлел в своей прозе колониальную повседневность Туркестанского края начала XX века. В его романе «Колонизаторы» (второе название - «Золотая паутина») все названо своими именами - так было принято до середины 1930-х гг.: «колониальное русское общество» [Чепрунов, с. 20], «темные стороны жизни колонии» [Там же, с. 33], в колониальных школах «не изучали ни обширного края, ни народа, его населяюшего. Детям внушалось презрение $и$ недоверие $\kappa$ мусульманамтуземцам и уважение к управителям края» [Там же].

Еще в начале 1930-х гг. термин колон и альная литература существовал в идеологически безоценочном дискурсе. C середины тридцатых власть грубо вмешивается в литературоведческую кухню. В публичном идеологическом пространстве появляется новая риторика антиколониальная, в основе своей противопоставленная колониальной политике царской России: «Обе революции 1917 года, временный распад империи, кровавая Гражданская война и установление большевистского режима с обещаниями построить новое общество на принципах, отрицающих колониализм, стимулировали в российских интеллектуальных кругах артикуляцию антиколониальных дискурсов» [Тольц, с. 169].

Русский прозаик XIX века Николай Каразин в советской историко-литературной табели, ранжирующей писателей, назван колониальным автором. То, как воссоздан колониальный проект по завоеванию Туркестанского края Российской империей в прозе Каразина - очевидца, участника русско-туркестанского проекта, противоречи- 
ло советским пропагандистским мифам, которые тиражировались на протяжении всего советского XX века. Проза Каразина разрушала благолепие русского присутствия в Туркестанском крае, поэтому она была изъята из круга чтения. После 1917 г. литературное творчество Каразина как бы перестало существовать - советские цензурные организации (Главлит и др.) вычеркнули его из литературной жизни. Наступило полное забвение - забвение двадцати томов прозы, опубликованной в виде полного собрания сочинений Н. Н. Каразина [Каразин] в 1905 г. (хотя были публикации детских книжек Каразина, не имевших отношения к главной теме творчества писателя колониальному проекту). «В области художественной литературы... ликвидировать литературу, направленную против советского строительства... <..> Можно и должно проявлять строгость по отношению к изданиям со вполне оформившимися буржуазными художественными тенденциями литераторов. Необходимо проявлять беспощадность по отношению к таким художественно-литературным группировкам...» [Лебедев-Полянский, с. 71-72] - так увековечил направление работы Главлита цензор П. И. Лебедев-Полянский, один из редакторов той энциклопедии, где в последний раз (в советский период) упомянут Каразин-литератор. (В 1992 г. появляется энциклопедическая статья о Каразине, возвращающая его в историю литературного процесса XIX в., см.: [Баскаков]).

Тиражировать и тем более исследовать тексты Каразина, содержание которых явно противоречило советской парадигме «дружбы народов», Главлит, вероятно, счел невозможным. В итоге колониальный проект на Восток вылился в некий оправдательный концепт, питающий чувство патриотизма и поддерживающий «особую миссию» русского мира. Этот концепт тиражируется до сих пор, например так: «Крестьянская реформа дала толчок развитию промышленности и торговли. Империя нуждалась и в новых рынках сбыта, и в источниках сырья, и в людских ресурсах для освоения присоединяемых территорий. Обширные среднеазиатские территории могли дать и то, и другое, и третье - если, конечно, поторопиться, не позволив чересчур активной в этом регионе Англии опередить себя» [Кудря, с. 57].

Колониальный дискурс из аналитического и критического в конце XIX в. превращается в первой половине XX в. в жизнеутверждающий, идущий по планете «русский мир», несущий благо, которое «равняется всему социализму» [Платонов, с. 503], - таков концепт счастья, представленный в колониальных текстах 1930-х гг. Анд- рея Платонова. Это «Джан», «Такыр». «Неизвестный цветок» - классический колониальный канон советского образца. «B аду твой народ уже был, пусть поживет в раю, а мы ему поможем всей нашей силой» [Там же, с. 412], - было сказано платоновскому Чагатаеву в «Центральном Комитете партии».

Широкие перспективы для постколониальных исследований представляет, по словам Ольги Брейнингер, эпоха Советского Союза [Брейнингер, с. 166]. Постколониальные проблемы в русской литературе стали подниматься много раньше крушения советской империи. В качестве примера остановлюсь на повести Юрия Карабчиевского «Тоска по Армении», написанной в 1978 г. - во времена глубокого советского «застоя». Рассказчик-путешественник, подготовленный к поездке в Армению любимым им Мандельштамом, ждет открытий, символически выраженных строкой поэта «Как живет в Эривани синица?». Однако перед глазами рассказчика предстают вполне знакомые картины советского быта, советской ментальности. Обескураженный, он бродит по Еревану: «Все как в Ленинграде или Москве...» [Карабчиевский, с. 202]. Не таким представлял он себе этот город, «какой-то он не армянский» [Там же, с. 194]. Здания производили впечатление временных - архитектура была «никакая, просто среднесоветская архитектура», «времен Днепрогэса и первых пятилеток» [Там же, с. 194]. Повсюду висели красные полотнища. Bce привычно, все как везде. Можно прочитать то, что написано на этих красных растяжках, даже не зная языка.

Четыре высокие буквы в самом конце, две разные и две одинаковые, и после них восклицательный знак - как знакомо, как будто всю жизнь читал поармянски! А вот немного другая фраза, тут в середине римские цифры, но и это нам тоже как семечки. Так легко перевести... [Там же, с. 194-195],

- без труда прочитывает рассказчик очередной лозунг о пронумерованном пленуме или съезде КПСС, лозунг, долженствующий вдохновить советского человека на текущие трудовые подвиги.

Впечатление, произведенное городом, - будто «выехали прежние жители и сразу въехало много армян» [Там же, с. 194], потому что город мало чем отличался от тех столичных локусов большой страны, к которым привык рассказчик: как и везде, главная улица - это «проспект, разумеется, Ленина» [Там же, с. 219]. Правда, люди другие, но декорации прежние - унифицирующие, нивелирующие какие-либо отличия, яв- 
но навязанные и силой привнесенные, насаженные как известная агрокультура.

Поражен не только взгляд рассказчика - советскими декорациями, уродующими древнейшую культуру Армении, поражен и слух - армянскими именами, для которых чужды русские антропонимические суффиксы - метаколониальной истории:

Амбарцум - хорошо. Амазасп - прекрасно. Но Амбарцум Амазаспович - это уродливо. Здесь не только борьба чужеродных звучаний, но и ярко выраженная подчиненность, клеймо государственности на лбу [Там же, с. 191].

Буквы армянского алфавита - графические символы культуры и истории, поражающие путешественников по Армении, - тоже попали под прессинг колониальной машины:

Документы, письма, две машинки... Русский шрифт! И опять русский! «Что вы, что вы, - машет рукой Норик, - армянская машинка - это редкость. $<\ldots>$ Все делопроизводство - только по-русски» [Там же, с. 193].

Но, как можно констатировать по прошествии сорока лет после написания травелога Карабчиевского, сила буквы, читай культуры, оказалась сильнее политики: армянский алфавит жив. Несмотря на то что власть делала много, чтобы унифицировать имена, буквы, чувства и мысли. Однако след - колониальный след - все же оставлен:

В русских школах преподают с армянским акцентом, а в быту не читают и не пишут по-армянски, и люди выходят в конце концов полуграмотные, не приобщенные ни к тому, ни к другому... [Там же, с. 264].

Неподцензурность травелога Карабчиевского выражена также литературными штрихами (литература при советской власти - объект ее пристального контроля). Паролем для распознавания своего становится имя «Набоков»- запрещенная при советской власти литературная фигура. Представляя читателю вновь приобретенного армянского друга, рассказчик замечает: «Но $\mathrm{Ha}$ бокова он тоже, конечно, читал...» [Там же, с. 250]. Помимо интеллектуального пароля, в повседневности присутствовал и иной - на предмет порядочности: «....мы долго друг к другу принюхивались на предмет стукачества» [Там же, с. 208].

Набоков упоминается еще раз - в ряду писателей, уничтоженных советской властью или подвергшихся обструкции: когда рассказчик вы- сказывается по поводу памятников - кому ставить, кому нет. Установка памятников в советской истории воспринимается как властное «принуждение и навязывание, насилие над свободой оценок и мнений» [Там же, с. 291].

Встретившись с Грантом Матевосяном, рассказчик делится своими печальными впечатлениями об Армении:

Ереван - не нравится. <..> Я спрашиваю Гранта, где же Армения, если не в Ереване, то где? <..> - Я теперь и не знаю, где Армения. <..> Нет Армении, Юра, где ни ищи, есть только наша тоска по Армении! [Там же, с. 266].

Главные слова, вынесенные в заглавие травелога, произнесены: «тоска по Армении» - тоска по уходящей культуре, по вековым ценностям и одновременно - возмущение навязанной моделью жизни, возмущение, перешедшее в тоскупечаль, которая проникла во все сферы бытия.

Рассказчик становится свидетелем застольной беседы:

Сталин был армянином, вот оно что! Мать его была армянкой, точно известно. А отец - грузин, но тоже, как будто, не очень. Еще надо выяснить... [Там же, c. 235].

Так, задолго до постколониальных процессов, ставших предметом изучения гуманитариев, Карабчиевский обозначил этот необычный феномен - присвоение, приватизация лидера метрополии. С одной стороны, подобные прецедентные процессы свидетельствуют о деформации сознания советского и постсоветского человека, сознания, предрасположенного к аберрации, с другой - о присущей ему мифологической органике вообще. «Ни империализм, ни колониализм не являются простыми актами накопления и приращения. Оба они поддерживаются и, возможно, даже приводятся в движение мощными идеологическими образованиями, которые включают в себя представление о том, что определенные территории и народы нуждаются и даже взывают о господстве над ними <...> [Caид, с. 51] (курсив автора. - Э. Ш.). Гегемония имперской идеологии охватила все колониальные культуры.

В заглавии «Тоска по Армении» звучат антиколониальные обертоны. По совокупности интенций и тематики повесть Карабчиевского могла быть напечатана только в отсутствии цензуры - в 1988 г. в «Литературной Армении». Удивляет пророчество Карабчиевского: он обозначил ряд векторов, которые актуализировались в контексте современных постколониальных штудий. 
Георгий Кубатьян, хорошо знавший Юрия Карабчиевского, пишет: «<... Политика как таковая ничуть его не привлекала. Перед нами писатель, поневоле политизированный. Он-то политикой не занимался, но в стране, где свободная мысль заведомо крамольна, писания Карабчиевского были непроходимы по причинам именно политическим» [Кубатьян, с. 252]. «Тоска по Армении» - весомое свидетельство как истории XX века, так и истории русской литературы.

Процессы, связанные с распадом советской империи и вписывающиеся в постколониальную проблематику, - основные в прозе современного писателя Сухбата Афлатуни (Евгения Абдуллаева). Постсоветские коллизии на окраинах бывшей империи присутствуют в его сюжетах на разных уровнях текста: композиционном, детальном, аксиологическом, символическом, локальном.

Один из главных постколониальных мотивов прозы Сухбата Афлатуни - гибель места, его стагнация. В контексте этого мотива рождается беспрецедентный в лексическом отношении образ лет аргар и я. В повести «Пенуэль» летаргарий - медицинское учреждение: туда свозят тех, кто заснул летаргическим сном, - так писатель метафоризирует постсоветское состояние отпочковавшихся от России среднеазиатских государств.

В последнее время в Средней Азии участились случаи тяжелой летаргии. С целью профилактики рекомендуется... <..> - Можем, конечно, прививку, но это, извиняюсь, за оплату. $<\ldots>$ А разве летаргия - заразная? <...> Главврач издал приказ, что заразная... [Афлатуни, 2007, с. 52-53].

В рассказе «Остров Возрождения» летаргарий предстает в виде острова смерти: читательская рецепция эсхатологического ландшафта попадает в зону усиления, создаваемую антиномичным заглавием. Реальное географическое название - остров Возрождения - становится символическим, расширительным, куда, помимо каракалпакских земель, входит и музей с собранием русского авангарда:

Музей авангарда, зеленоватые лица, поломанные тела. Мир, разваливающийся на первоэлементы. < ..> Иссякло море, оставив торчащие в песках скелеты кораблей - лучшую инсталляцию века. Лица людей, небо, земля - все постепенно становилось как на картинах. Даже еще авангарднее [Афлатуни. Остров Возрождения, с. 93-94].

Мудак у вас шофер! - От такого слышу! - улыбнулся ему в спину шофер. <...> - Вот из-за таких, как ты, и Чернобыль, и все. - А из-за тебя - Союз! [Там же, с. 112-113]
- препираются персонажи, им до сих пор трудно смириться с распадом империи. Они обвиняют в этом местного юродивого:

Его звали «Горбачев». Или «Михаил Сергеевич». Как кому нравилось. Возник он, как и все на острове. Из пустоты. Из ветра-шалуна. Из капсулы с порошком сибирской язвы (возможно, несуществующей). $<\ldots>$ Другие говорили, что он пришел на остров после того, как контингент исчез $<\ldots>$ унесся в сторону России. $<\ldots>$ Горбачев стал хозяином острова [Там же, с. 100-101], хозяином этой «ничто-земли» [Там же, c. 117].

В рассказе «Жало» [Афлатуни. Жало] атмосфера стагнации места и его культуры выражена не только сменой алфавита (кириллицы на латиницу), но и «рубежной языковой компетентностью»: рассказчик толком не знает ни родного языка, ни языка, привнесенного колонизаторами. Потому что «люди непереводимыл. Нельзя их вынимать, как слова, из одного языка и, лишая памяти, родины, детства - перетаскивать в другой» [Афлатуни. Ташкентский роман, с. 209] говорится в другой повести - «Ташкентский роман» - Сухбата Афлатуни.

Одна из главных героинь рассказа «Жало» Вик-Ванна (Виктория Ивановна), пожилая русская женщина, прошедшая войну, орденоносец. По бывшей советской традиции и инерции в Узбекистане, независимом государстве, где происходит действие рассказа, отмечают День Победы. Вик-Ванна вместе с другими ветеранами войны приглашена на праздник. Празднование организовано по утвержденному сценарию помпезно и бесчеловечно. Однако в традицию вплетен новый постколониальный штрих. ВикВанне повезло: она попала в объектив телевизионщиков.

Стоп! Мать вашу! Почему советские медали? Отколите советские или ладонью прикройте, да... хотя бы так. Переснимаем [Афлатуни. Жало, с. 165].

Вик-Ванне нет места в этом времени, оно для нее остановилось.

В центре сюжета повести-притчи «Глиняные буквы, плывущие яблоки» воссоздана жизнь условного среднеазиатского локуса, в прошлом колониальной «лаборатории» по созданию «нового советского человека». Читатель застает жизнь этого места в точке выхода из «русской империи»: «<...> Москва нашей столицей быть расхотела...» [Афлатуни. Глиняные буквы..., с. 13]. Исчезла вода, умирает все живое. Однако по-прежнему жизнь воспринимается, как учили в советской школе (и в этом месте тоже), литера- 
туроцентрично. Преподавание литературы Старым учителем (то есть советским) породило в сознании жителей этого места уродливые и комические аберрации: «... в России хороших поэтов много, в России вода есть» [Там же, с. 21], Лермонтов - первый русский космонавт [Там же, c. 8], «Владимир Ил ь и ч Маяковский» (выделено нами. - Э. $Ш$.) [Там же, с. 21].

Эсхатологизм ландшафта притчи провоцирует на поиск морализаторской сути: за что пострадали жители этого места? Они то и дело вспоминают недавнее прошлое: «Когда у нас русские жили...» [Там же, с. 19], «отношения с Россией сейчас неопределенные...» [Там же, с. 13], «Когда в село советская власть пришла...» [Там же, с. 24]. За этот не столь большой исторический период был утрачен древний алфавит, поиском которого занят Молодой учитель представитель забытого, но возрожденного им учения - суфизма. Когда он нашел последнюю букву, необходимую для пения сакральной молитвы, все вернулось: и вода, и красота, и жизнь; исчезли сатрапы, но главное - была предотвращена трагедия, казнь Молодого учителя.

Средняя Азия на страницах прозы Сухбата Афлатуни, погрузившись в летаргари й, безвременье, безусловно, разделила судьбу всей империи. Среднеазиатское безвременье изображено в его повести «Год барана» [Афлатуни, 2011] как завершающая фаза колонизации. «Баран» в заглавии и «баран» в качестве многофункциональной детали в сюжете повести стал приметой безвременья, истоки которого в виде аллюзии отсылают к «баранине» из «Господ ташкентцев» Михаила Салтыкова-Щедрина. Щедрин не менее умышленно, чем Сухбат Афлатуни, акцентирует эту деталь: «да разве вы не сльишали, какая у них там баранина», "баранина, я вам скажу», «я слышал, что баранину можно достать отличную», «да там, говорят, такая баранина», «баранина от многих недугов исиеляет!», «они по постам баранину лопают» - «такова судьба иивилизующего начала! Оно истребляет туземных баранов и, взамен того, научает обывателей удовлетворяться духовною пищею!» [Салтыков-Щедрин, с. 45-47].

Образ летаргария окончательно сформирован в рассказе Сухбата Афлатуни «Русский музей». Собственно постколониальность воплощена в метафоре «музей». В тексте рассказа мелькнула деталь - старый дом «колониальной постройки» [Афлатуни. Русский музей, с. 14]. Колониальная интенция рассказа сопряжена с образом героя по имени Сергей. Воспитанный русской няней Баболей, эвакуированной в Среднюю Азию ленинградкой, мальчик получил от нее не только рус- ское имя (взамен Сиродижина), но и трепетное отношение к вещам как предметам с биографией - «в нем проснулся коллекиионер» [Там же, с. 15]. Он стал собирать вещи отъезжавших русских.

Со временем, когда они все уедут, а оставшиеся растворятся среди местных, он откроет частный музей. В него будут приходить люди и удивляться [Там же, с. 15].

Страстным желанием было получить по смерти Баболи ее «царскую кровать», сделанную на заказ еще в военное время. Но кровати больше нет.

Когда на похоронах ее потребовалось немного сдвинуть, она рассыпалась. Пришедших было много. Многие еще помнили Баболю. Каждый унес на память по фрагменту развалившейся кровати [Там же, с. 19].

Эти обломки - символический артефакт «цивилизаторского проекта», стартовавшего в XIX в.

Постколониальность в современной литературе зашифрована не только в притчевых символах и метафорах, она породила феномен mentalis loci: после развала империи многие прозаики и поэты вынуждены были мигрировать вслед за русским языком своего творчества, являя в литературе некое культурное двойничество: «Полукровство явило новую „микрорасу“ со своим особым менталитетом. Русская литературная речь, привитая элитной прослойке коренных жителей азиатских республик, приносила в сочетании с традиционно восточным укладом быта и мышления весьма неожиданные плоды» [Янышев, Афлатуни, Муратханов, с. 107]. Таким «неожиданным» голосом создает лирическую прозу московский поэт Санджар Янышев. В портрете и мироощущении его лирического субъекта угадываются черты постимперского, или постколониального, сознания - по хронотопу и метиссажу. Остановимся на одном примере - «Баллада о патыре». Перед нами эпический сюжет - частный случай войны на фоне вселенского военного события: раненые, изголодавшиеся, умирающие бойцы, которых взялся спасти «партизан Азамат Рустамов». Первым делом - во спасение «он отправился на поиски глиныл» [Янышев, 2017 c. 74]. (Был в истории культуры подобный сюжет с подобным же вектором: во спасение евреев, которые должны были погибнуть в очередном погроме, рабби Лейб отправился на поиски глины, чтобы слепить из нее Голема. К рабби пришел один из тридцати шести тайных праведников: 
«Сделайте голема, и он вас спасет. - Голема? Как это? Из чего? - Из глиныл» [Зингер, с. 20].)

Азамат Рустамов делает из глины тандыр, среднеазиатскую печку, чтобы испечь в ней лепешку, которая спасет всех от голодной смерти. Но это не простая лепешка - это патыр. Его в народе называют долгоиграющей лепешкой, с нею отправлялись в путь через пустыню караванщики.

<..> Последняя картофелина была подавлена в кашицу, растерта в порошок рукояткой нагана. / Рустамов снял с шеи тряпицу, внутри оказались сухие белесые почки какого-то растения. / «Исрык», - пояснил (специально для Суслика), растолок и всыпал в муку. / Туда же замешал горсть золы и каплю древесной смолы. / Сформованный блин он прилепил к внутренней стенке вулкана — над тлеющими углями... / «Бу менинг Мухаббат!» - сказал Рустамов. / Каждый из пятнадцати взял по горячему кусочку патыра. / Мой кусок все еще у меня, вот он. / Свидетельствую: все уцелели [Янышев, 2017, с. 75].

Голем в иудаистской мифологии - версия Спасителя (Машиаха, Мессии), приход которого бесконечно ожидает еврейский народ. В череде спасителей, с точки зрения иудеев, был Иисус Христос. Но все они: и Голем, и Христос, и еще много других - в итоге не оправдали ожидания иудеев. В отличие от рецепции последователей Христа - они признали в нем Спасителя. Это он «взял хлеб и, благословив, преломил и, раздавая ученикам, сказал: приимите, ядите: сие есть Тело Мое» (Мф. 26:26). Так работает метатекст глобальная культура, осознанно или опосредованно явленная в «Балладе о патыре». Так в один культурологический ряд встроены Голем,

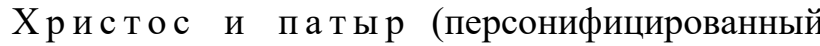
«Азамат Рустамов»). И если еврейского Голема надо было оживить начертанным на его лбу одним из имен бога, то жизнь патыру дают не менее сакральные слова «Бу менинг Мухаббат» это моя любовь (где Мухаббат означает и любовь, и женское имя). (Или, по евангелической версии, это тело мое).

Почему Санджар Янышев обращается к теме войны? Одна из причин очевидная, связанная с постколониальной рецепцией. Россия приватизировала победу во Второй мировой. Победа стала русским брендом. А как же узбеки? Череда нынешних поколений не знает, какую поддержку и помощь внесла в общую победу Средняя Азия.

$<\ldots>$ В своем Хлебном Городе мы принимаем беженцев и делим с ними лепешку, делим кишмиш, делим всякую участь. / Мы сами эвакуанты [Янышев, 2017, c. 23].
Дед лирического героя «из Берлина с щиитом вернулся...» [Там же, с. 13].

Так, перетекая из одной культуры в другую, из современности в прошлое, из страны и языка предков в свое нынешнее состояние, метаморфизируясь, перевоплощаясь, лирический субъект Янышева, с одной стороны, сопряжен с колониальной историей бывшей империи, которая считывается в виде палимпсеста в повествовании лирической прозы, с другой - его сознание воплощает постколониальную рецепцию. Это вполне осознанная и артикулированная автором позиция, выраженная в поэтическом манифесте: «Мы всегда подчеркиваем уникальность пространственно-временного контекста, возникшего на окраине некогда великой Империи» [Янышев, 2004 , с. 5]. Собственно в этом и заключается суть постколониальной рефлексии - в понимании и приятии мультикультурной обреченности.

\section{Список литературы}

Афлатуни С. Глиняные буквы, плывущие яблоки: Повесть-притча. Октябрь. 2006. № 9. С. 3-63.

Афлатуни С. Год Барана: Макамы // Дружба народов. 2011. № 1. С. 40-96.

Афлатуни С. Жало: Рассказ // Сухбат Афлатуни. Дикий пляж: Сб. рассказов. М.: Рипол классик, 2016. C. 134-184.

Афлатуни С. Остров Возрождения: Рассказ // Сухбат Афлатуни. Дикий пляж: Сб. рассказов. М.: Рипол классик, 2016. С. 89-118.

Афлатуни С. Пенуэль: Повесть // Октябрь. 2007. № 9. C. 3-73.

Афлатуни С. Русский музей // Сухбат Афлатуни. Дикий пляж: Сб. рассказов. М.: Рипол классик, 2016. C. $5-19$.

Афлатуни С. Ташкентский роман. СПб.: Амфора, 2006. $239 \mathrm{c}$.

Баскаков В. Н. Каразин Николай Николаевич // Русские писатели. 1800-1917: Биографический словарь. Т. 2: Г-К. Гл. ред. П. А. Николаев. М.: Большая Российская энциклопедия, 1992. С. 468-469.

Брейнингер $O$. Безмолвный протест // Октябрь. 2012. № 10. С. 166-169.

Зингер И.-Б. Голем и другие рассказы для детей / пер. с англ. М.: Лехаим, 2003. 160 с.

Карабчиевский Ю. Тоска по Армении // Ю. Карабчиевский. Тоска по дому: Роман, повести. М.: Слово, 1991. С. 185-296.

Каразин Н. Н. Полное собрание сочинений: в 20 томах. СПб.: изд. П. П. Сойкина, 1905.

Кубатьян Г. Масштаб явления. Армянская проза В. Гроссмана, А. Битова и Ю. Карабчиевского // Кубатьян Г. Ворованный воздух: Статьи и заметки. Ереван: РАУ, 2005. С. 238-253.

Кудря А.И. Верещагин. М.: Молодая гвардия, 2010. $428 \mathrm{c}$. 
Лебедев-Полянский П. И. Из докладной записки Оргбюро ЦК ВКП(б) о деятельности Главлита // Власть и художественная интеллигенция: Документы ЦК РКП(б) - ВКП(б), ВЧК - ОГПУ - НКВД о культурной политике. 1917-1953 / под ред. А. Н. Яковлева. М.: МФД, 2002. С. 70-74.

Платонов А. Избранные произведения. М.: Экономика, $1983.880 \mathrm{c}$.

Саид Э. В. Культура и империализм. СПб.: Владимир Даль, 2012. 734 с.

Салтыков-Щедрин М. Е. Собрание сочинений: в 20 томах. М.: Художественная литература, 1970. Т. 10. $839 \mathrm{c}$.

Тольи В. «Собственный Восток России»: Политика идентичности и востоковедение в позднеимперский и раннесоветский период. М.: Новое литературное обозрение, 2013. 336 с.

Чепрунов Б. Золотая паутина: Роман. Ташкент: Ёш гвардия, 1963. 302 с.

Эткинд А., Уффельманн Д., Кукулин И. Внутренняя колонизация России: между практикой и воображением // Там, внутри: Практики внутренней колонизации в культурной истории России: сб. статей. М.: Новое литературное обозрение, 2012. С. 6-54.

Янышев С. Еще раз про золотое сечение, или Final cut // Малый шелковый путь: Новый альманах поэзии. Вып. 5. Ташкент: Фан, 2004. С. 5-6.

Янышев С., Афлатуни С., Муратханов В. Групповой портрет: О русской узбекской поэзии // Арион. 2001. № 3. С. 107-108.

Янышев С. Умр: Новая книга обращений. М.: Арт хаус медиа, 2017. 144 с.

\section{References}

Aflatuni, S. (2006). Glinianye bukvy, plyvushchie iabloki [Clay Letters, Floating Apples]. Povest'-pritcha. Ok-tiabr'. No. 9, pp. 3-63. (In Russian)

Aflatuni, S. (2011). God Barana [The Year of a Ram]. Makamy. Druzhba narodov. No. 1, pp. 40-96. (In Russian)

Aflatuni, S. (2016). Ostrov Vozrozhdeniia [The Island of Renaissance]. Rasskaz. Sukhbat Aflatuni. Dikii pliazh. Sb. rasskazov. Pp. 89-118. Moscow, Ripol klassik. (In Russian)

Aflatuni, S. (2007). Penuel' [Penuel]. Povest'. Oktiabr'. No. 9, pp. 3-73. (In Russian)

Aflatuni, S. (2016). Russkii muzei [The Russian Museum]. Sukhbat Aflatuni. Dikii pliazh. Sb. rasskazov. Pp. 5-19. Moscow, Ripol klassik. (In Russian)

Aflatuni, S. (2006). Tashkentskii roman [The Tashkent Novel]. 239 p. St. Petersburg, Amfora. (In Russian)

Aflatuni, S. (2016). Zhalo [A Sting]. Rasskaz. Sukhbat Aflatuni. Dikii pliazh. Sb. rasskazov. Pp. 134184. Moscow, Ripol klassik. (In Russian)

Baskakov, V. N. (1992). Karazin Nikolai Nikolaevich [Karazin Nikolay Nikolaevich]. Russkie pisateli. 1800 1917: Biograficheskii slovar'. T. 2: G-K. Gl. red. P. A. Nikolaev. Pp. 468-469. Moscow, Bol'shaia Rossiiskaia entsiklopediia. (In Russian)

Breininger, O. (2012). Bezmolvnyi protest [The Silent Protest]. Oktiabr'. No. 10, pp. 166-169. (In Russian)
Cheprunov, B. (1963). Zolotaia pautina [The Golden Web]. Roman. 302 p. Tashkent. Esh gvardiia. (In Russian)

Etkind, A., Uffel'mann, D., Kukulin, I. (2012). Vnutrenniaia kolonizatsiia Rossii: mezhdu praktikoi $i$ voobrazheniem [Internal Colonization of Russia: Between Practice and Imagination]. Tam, vnutri: Praktiki vnutrennei kolonizatsii $\mathrm{v}$ kul'turnoi istorii Rossii: sb. statei. Pp. 6-54. Moscow, Novoe literaturnoe obozrenie. (In Russian)

Ianyshev, S. (2004). Eshche raz pro zolotoe sechenie, ili Final cut [Once Again about a Golden Ratio, or Final Cut]. Malyi shelkovyi put': Novyi al'manakh poezii. Vyp. 5, pp. 5-6. Tashkent, Fan. (In Russian)

Ianyshev, S. (2017). Umr: Novaia kniga obrashchenii [Umr: A New Book of References]. 144 p. Moscow, Art khaus media. (In Russian)

Ianyshev, S., Aflatuni, S., Muratkhanov, V. (2001). Gruppovoi portret: O rus-skoi uzbekskoi poezii [A Group Portrait: On Russian Uzbek Poetry]. Arion. No. 3, pp. 107-108. (In Russian)

Karabchievskii, Iu. (1991). Toska po Armenii [Longing for Armenia]. Iu. Karabchievskii. Toska po domu: Roman, povesti. Pp. 185-296. Moscow, Slovo. (In Russian)

Karazin, N. N. (1905). Polnoe sobranie sochinenii [Complete Works]. V 20 tomakh. St. Petersburg, izd. P. P. Soikina. (In Russian)

Kubat'ian, G. (2005). Masshtab iavleniia. Armianskaia proza V. Grossmana, A. Bi-tova $i$ Iu. Karabchievskogo [The Scale of the Phenomenon. Armenian Prose by V. Grossman, A. Bitov, and Y. Karachevskiy]. Kubat'ian G. Vorovannyi vozdukh. Stat'i i za-metki. Pp. 238-253. Erevan, RAU. (In Russian)

Kudria, A. I. (2010). Vereshchagin [Vereshchagin]. 428 p. Moscow, Molodaia gvardiia. (In Russian)

Lebedev-Polianskii, P. I. (2002). Iz dokladnoi zapiski Orgbiuro TsK $\operatorname{VKP}(b)$ o deiatel'nosti Glavlita [From the Report of the Organizational Bureau of the Central Committee of All-Union Communist Party (Bolsheviks) about Glavlit's Activity]. Vlast' i khudozhestvennaia intelligentsiia: Dokumen-ty TsK RKP(b) - VKP(b), VChK - OGPU - NKVD o kul'turnoi politike. 1917-1953 / pod red. A. N. Iakovleva. Pp. 70-74. Moscow, MFD. (In Russian)

Platonov, A. (1983). Izbrannye proizvedeniia [Selected Works]. 880 p. Moscow, Ekonomika. (In Russian)

Said, E. V. (2012). Kul'tura i imperialism [Culture and Imperialism]. 734 p. St. Petersburg, Vladimir Dal'. (In Russian)

Saltykov-Shchedrin, M. E. (1970). Sobranie sochinenii [Collected Works]. V 20 tomakh. T. 10. 839 p. Moscow, Khudozhestvennaia literatura. (In Russian)

Tol'ts, V. (2013). "Sobstvennyi Vostok Rossii": Politika identichnosti $i$ vo-stokovedenie v pozdneimperskii i rannesovetskii period ["Russia's Own East": The Policy of Identity and Oriental Studies during the Late Imperial and Early Soviet Period]. 336 p. Moscow, Novoe literaturnoe obozrenie. (In Russian)

Zinger, I.-B. (2003). Golem i drugie rasskazy dlia detei [The Golem and Other Stories for Children]. Per. s angl. 160 p. Moscow, Lekhaim. (In Russian) 
The article was submitted on 05.03.2019

Поступила в редакцию 05.03.2019

\section{Шафранская Элеонора Федоровна,} доктор филологических наук, профессор,

Московский городской педагогический университет,

121069, Россия, Москва,

2-й Сельскохозяйственный проезд, 4. shafranskayaef@mail.ru

\section{Shafranskaya Eleonora Fedorovna,}

Doctor of Philology,

Professor,

Moscow City Teacher's Training University,

4 Vtoroy Sel'skokhozyaystvennyy Proyezd, Moscow, 121069, Russian Federation. shafranskayaef@mail.ru 